\title{
Gascoigne's Accidents: Contingency, Skill, and the Logic of Writing
}

In the letter to Sir Walter Ralegh "annexed" to the first three books of The Faerie Queene in 1590, Edmund Spenser undertakes to reveal "the general intention and meaning" of his poem “without expressing of any particular purposes or by-accidents therein occasioned." This distinction reappears at the end of the letter, which explains that "by occasion" of the main structure of the story "many other aduentures are intermedled, but rather as Accidents, then intendments." The accidents to which Spenser refers are not simply the carefully plotted incidents of the artful epic poet, designed to ensure plausibility or to provide additional interest by ornamenting the main plot. Instead, accident and intention are understood as opposed but necessary elements of the process of literary composition; Spenser seems to admit that unexpected events occur even in the execution of a rationally worked-out plan for poetic invention, leaving an indelible mark on the finished product. The Aristotelian metaphysical, logical and ethical framework on which Spenser's letter and his poem rely determines that the poem is indeed a "whole," unified by the final cause or "generall end... of all the booke"; but not all of the poem's elements are wholly subordinate to this telos, nor indeed are they all aimed at any target or scope. Artful intention, if understood as the coherent direction of all of the poet's and the poem's resources towards a single goal, is deemed inadequate to describe how the poem came to be and what the poem does. ${ }^{1}$

This essay argues that for George Gascoigne (one of Spenser's most important English predecessors, both for his poetic example and for his pioneering attempts to reflect critically on his own practice) accident plays a central role in coming to terms with the nature, status and 
permanence of his literary compositions. Many of his writings are occasional, or are at least presented as such, but Gascoigne mooted different ways in which such texts might transcend the particularity of their provenance to form part of a more enduring body of work. In the book that inaugurated his brief but busy career as a writer in print, A Hundreth Sundrie Flowres (1573), Gascoigne harnessed the still emerging form of the printed literary miscellany to explore the kinds of corpus that might emerge when works of varied occasion and genre were bundled together. The book purports to be a miscellany composed of translations from "Euripides, Ovid, Petrarke, Ariosto, and others" and original works by "sundry Gentlemen," but was in truth almost entirely written by Gascoigne. ${ }^{2}$ The volume challenges its readers with the problem of its own unity, and asks us always to think about the degree to which it has itself been shaped by both accident and intention. In so doing it plays out on a larger scale a drama visible in the varied individual works that it contains.

II

Before turning to Gascoigne's verse, I begin with his Certayne notes of Instruction concerning the making of verse or ryme in English, a ground-breaking if short and piecemeal critical reflection on poetic practice with a particular emphasis on metre, first printed in The Posies of George Gascoigne, a revised edition of A Hundreth Sundrie Flowres published in 1575. (The Posies removed the fiction of multiple authorship, presenting the collection as the work of a single author with explicit though possibly disingenuous claims to didactic intent.) In starting with the Notes, I do not mean to suggest that by dealing with Gascoigne's poetic theory we can grasp all 
that must be understood about his poems: indeed, while his metrical precepts and his stress on grounding poems "upon some fine invention" are clearly relevant to his own works, Gascoigne himself does not offer a systematic poetics which coolly governs the act of writing from a distant or elevated position of intellectual abstraction. Instead, these are precepts hard won from experience and designed to help the poet in the most immediate and practical ways in any of the myriad occasions that might give rise to poetic composition: "To deliver unto you generall examples it were almoste unpossible, sithence the occasions of Inventions are (as it were) infinite" (p. 455). Many of the precepts are formulated as warnings to a poet always in danger of straying from the rational plan with which he begins his work: "take heede that neither pleasure of rime, nor varietie of devise, do carie you from it"; "hold the just measure wherwith you begin your verse"; "remembre to place every worde in his natural Emphasis"; “beware of rime without reason" (pp. 455-58). Gascoigne's task is to "forewarne" (p. 457) his reader of potential errors, which are not merely acts of wandering but of falling: "I do see and read many mens Poems now adayes, whiche beginning with the measure of .xii. in the first line, and .xiiii. in the second... they wil yet (by the time they have passed over a few verses) fal into .xiiii. and fourtene, and sic de similibus, the which is either forgetfulnes or carelesnes"' (p. 456). Similarly: "I can lament that wee are fallen into suche a playne and simple manner of wryting, that there is none other foote used but one" (p. 457). As we shall shortly see, Gascoigne's works consistently return to a language of falling (to which are related the terms accident, incident, occasion and case, all derived from Latin cadere, to fall); Gascoigne's Notes offer some measure of protection against the accidents which may befall the poet. 
Gascoigne's sense that both the genesis of the individual poem and the course of literary history are processes imbued with value by a normative direction and purposiveness, but liable to fall short of their potential if accident trumps intention, finds an echo in one of the few poems on which Gascoigne's modern reputation is based: "Gascoignes Wodmanship." ${ }^{3}$ Embarrassed by his failure in hunting, Gascoigne asks Lord Grey to "wonder not, / To see [his] wodman shoote so ofte awrie" (p. 312, 72.1-2), since "He shootes awrie almost at every marke" (p. 313, 72.14). There follows a catalogue of failed worldly gambits, all figured as errant arrows: Gascoigne's attempts to be a student of philosophy, then of law; his uneven career at court; his disillusioning experience of soldiery. The poem establishes that the stray falling of these arrows is, for Gascoigne, the norm; and it imbues this norm with the philosophically privileged status of a "cause" (p. 313, 72.10). The fallen arrows of Gascoigne's life, which might individually appear to be accidents without further significance, coalesce to form a broadly coherent picture of failure for which Gascoigne is at least partly responsible. But the poem adumbrates another coherent picture too, by asking, in effect: is there providence in the fall of an arrow? Perhaps there is: error, mistaking one's mark, shooting awry - things that disturb the marriage of efficient and final causes by producing outcomes which are strictly accidental - are rehabilitated by the artful invention of Gascoigne's poem into a teleological scheme. Indeed, Gascoigne explicitly replaces a vision of a world governed by "chaunce," in which the dominant human experience is one of "lacke of skill or fortune" (p. 316, 72.134), with one based on providence, in which “Jehova” sends a doe into Gascoigne's path “That by the sodaine of hir overthrowe, / [He] might endevour to amende [his] parte" (p. 316, 72.136-40). This determination to rewrite accident as providence mirrors the rhetorical action of the poem: shooting awry before Lord 
Grey becomes the "cause" of Gascoigne's self-justification and the motive for this piece, which exerts a powerful control over contingency through its clarity of structure and argument. An apologia pro vita sua, occasioned by one more erroneous arrow, becomes a job application in which Gascoigne asks Grey “To traine him yet into some better trade” (p. 314, 72.70): Gascoigne himself becomes an arrow to be aimed by Grey at some purposeful action.

That Gascoigne is knowingly toying with Aristotelian notions of causality, virtue, and artfulness, despite the acknowledged failure of his early attempts at philosophy, is made clear by his references to the philosopher: "In Aristotle somewhat did I learne, / To guyde my manners all by comelynesse" (p. 315, 72.101-2). Aristotelian ethics is thus one of the principal frames of reference through which we are invited to understand the poem. Here, the wiser voice of the latter part of the poem reassesses his earlier errors and salvages from them what he can, revaluing the modicum of knowledge and ability he has gleaned, and positing a behavioural ideal which is thoughtful, rational, purposeful, self-aware and self-possessed. The guiding of his manners suggests action oriented towards an end, which is in this case not the target (skopos) of the archer-a specific goal on a specific occasion-but the general end (telos) of virtue, defined by Aristotle as a purposive or choice-making disposition or habit (hexis proairetikē) which observes the mean. ${ }^{4}$

Roger Ascham's dialogue Toxophilus (1545, republished in 1571), which Gascoigne probably had in mind in writing his "Wodmanship," had recently established that the subject of archery was a worthy basis for philosophical speculation. The dialogue begins with the eponymous archer, lost in the study of Plato's Phaedrus and understandably attracted by its description of those "well fethered" souls that fly in the heavenly realms and those with 
damaged feathers that "sanke downe into earthlie thinges." ${ }^{5}$ More important to the dialogue as a whole, however, is the question of human artfulness - specifically, its capacity to exercise control over contingency and accident, and its limitations therein. Plato's discussions of the status of rhetoric in the Gorgias and Phaedrus, asking whether it is a true art (technē) or a mere knack (empeiria) or artless practice (atechnos tribē), are implicitly at work here, as are some related Aristotelian ideas about causality, skill, and intention. ${ }^{6}$ Aristotle makes regular use of an association between the very idea of technē (a habit, guided by reason, rendering the individual capable of making things, according to the special end or telos of each particular art), virtue (a habit which aims at the mean), and archery. The Nicomachean Ethics begins with the statement that every technee, inquiry or undertaking seems to aim (ephiesthai) at some good. ${ }^{7}$ In all virtues, one aims at a certain mark (skopos) and increases or slackens the tension accordingly (echōn epiteinei kai aniēsin). ${ }^{8}$ Virtue itself is a state skilful in hitting the mean (stochastike tou mesou). ${ }^{9}$ This language extends beyond the treatment of virtue to other areas of Aristotle's description of human modes of thought: in the Posterior Analytics, his account of rationally demonstrated knowledge and definition, Aristotle discusses another kind of mean or meson, the middle term of the syllogism, and notes that quick-wittedness (agchinoia) discerns the middle term without hesitation through a certain skill in hitting the mark (eustochia). ${ }^{10}$ Aristotle's establishment of this metaphorical nexus at the very core of his thinking on ethics and human skill presents Ascham with a double opportunity to discuss philosophical concerns through the subject of archery and to show what is philosophical within archery itself, a pursuit whose only end is "to hyt the marke" (p. 69) and which is thus a good analogue for any purposeful or targeted human action: "Aristotle him selfe sayth that shoting and vertue be very like" (p. 10). 
Toxophilus builds on this philosophical tradition by asking how far the practice of archery may be reduced to a set of principles and thereby taught. Toxophilus himself is skeptical about this: "how the thing is to be learned I will surely leue to some other which bothe for greater experience in it, \& also for their lerninge, can set it out better than I" (p. 6). The dialogue's two characters-one an archer and amateur philosopher, the other a scholar-stand for distinct human competences, for theory and practice. Ascham never quite suggests that these can be brought perfectly into alignment: there must be some gap between abstract reasoning and lived experience. To be sure, Toxophilus's intelligence and autodidactic learning are presented with great sympathy; he knows that the man with the right sort of experience and intelligence "myght soone with diligent obseruynge and markynge the hole nature of shootynge, find out as it were an Arte of it" (p. 60), but he has sufficient self-knowledge to concede that he could never meet Aristotelian standards of certainty and precision in so doing. Both speakers agree that "cumlynesse," in which virtue itself consists, cannot be taught (p. 103). And this is not the only thing that lies outside the bounds of precept: as the dialogue draws to a close much attention is given to the nature of wind and weather, the "greatest enemy of shootyng..., wherby true kepyng a lengthe is chefely hindered. If this thing were not, men by teaching might be brought to wonderful neare shootynge" (p. 106). Toxophilus boldly acknowledges that contingencies outside the agent's control are the largest factor militating against practical success and mitigating the adequacy of theory and doctrine. Earlier in the dialogue this problem is explicitly aligned with the difficulty of writing, in terms that closely anticipate Gascoigne's stress on the infinitude of possible occasions for composition in the Certayne notes: the exact dimensions of the arrows to be used by individual archers "can not be 
toulde no more than you Rhethoricians can appoynt any one kynde of wordes, of sentences, of fygures fyt for euery matter, but euen as the man and the matter requyreth so the fyttest to be vsed" (pp. 84-85).

It is not quite sufficient, then, to say with Thomas Greene that Ascham "preferred learning by precept to experience."11 Rather, Ascham's writing displays a philosophical awareness of the difficulty and situatedness of attempts at pedagogy, and a nuanced acknowledgement of the indeterminacies of both experience itself and attempts to generalise from it. Jonathan Crewe sees “Gascoignes Wodmanship” as antagonistic towards Ascham's humanist paradigm, but this is an unnecessary opposition, which does a disservice to the ethical complexity and breadth of vision inherent in humanist practice itself. ${ }^{12}$ Not only would it be unfair to paint Ascham as the staid representative of precept and pedagogical pedantry; it would also be wrong to understand Gascoigne as a poet incapable of philosophical insight or ignorant of moral philosophy. Gascoigne's attendance at Cambridge would have been quite sufficient to have exposed him to the kind of rudimentary conceptual apparatus of Aristotelian ethics that informs his "Wodmanship." He may not have taken a degree (a common phenomenon), but one should not infer from contemporary references to his lack of higher learning that he had no learning at all. ${ }^{13}$ Gascoigne and Ascham need only be understood as different in degree rather than in kind, and certainly not as diametrical opposites in an Elizabethan culture war. Acknowledging with Plato and Aristotle the deep interrelation of chance $(t u c h \bar{e})$ and art (technēe, which operate in the same world upon the same class of things, both Gascoigne and Ascham confront the need for, and limitations of, methodically disposed precepts as tools for learning and guides for action. ${ }^{14}$ 
Gascoigne writes in his "Wodmanship" of his failure as a student of law:

Next that, he shot to be a man of lawe,

And spent some time with learned Litleton,

Yet in the end, he proved but a dawe,

For lawe was darke and he had quickly done.

Then could he wish Fitzharbert such a braine,

As Tully had, to write the law by arte,

So that with pleasure, or with litle paine,

He might perhaps, have caught a trewants parte. (p. 313, 72.21-28)

Here Gascoigne gestures towards an important early modern jurisprudential debate about the extent to which English law might be reduced to the streamlined, artificial form favoured by so many textbook writers during the sixteenth-century rage for method. ${ }^{15}$ The collections of cases and "forms of action" compiled by Sir Anthony Fiztherbert, designed to be usefully compact texts, are criticised for their lack of methodical disposition. ${ }^{16}$ Confronted by the difficulty of the law, the younger Gascoigne yearns for the existence of a textbook which might lay out the bare essentials in an orderly manner; later, he realises that such a book would leave him only with a specious substitute for true learning, an implicit acknowledgement that the intractable detail of the law is, despite its messiness and miscellaneity, the very site of its meaning and power. The promise of method is false, qualified and so made redundant by Gascoigne's use of the word "perhaps": even an explicit meditation on the utility of clear textual order is contaminated by 
Gascoigne's pervasive sense of contingency. Gascoigne, like Ascham, knows that irreducible particularity at some point defeats reasoned generalisation and principle.

Gascoigne consistently demonstrates an awareness of the questions raised by the fashion for order and method in later humanist pedagogy. In 1575 he published The Noble Arte of Venerie or Hunting (a translation from French), whose status as an ordered ars venationis is made plain by its copious references to its own "order" (two of them on the title-page alone), and by its stated aim of providing "an exquisite tradition \& methode of those two Artes."17 Like a host of other contemporary texts, such as Thomas Blundeville's A Newe Booke Containinge the Arte of Ryding (1561), The Noble Art attempts what Ascham's Toxophilus had mooted: a reliable, methodical guide to a difficult activity beset by innumerable contingencies. In another publication of 1575, the moralistic play The Glasse of Governement, Gascoigne offers an exploration of the nature and effects of humanistic pedagogy. Charged with the education of four boys, the tutor Gnomaticus tries to "determine what trade or Methode shalbe most convenient to use in teaching" them. ${ }^{18}$ Several references are made to the concept of the "order of teaching" (pp. 17, 18, 34); one of the younger and slower boys tells Gnomaticus that his "order of teaching is... very compendious" (p. 28), and asks for a more detailed kind of instruction to assist his learning. The play draws a stark contrast between the earnest younger boys who learn their lessons slowly and well, and the quick-witted older ones who abandon the tedious shallowness of methodical didacticism for the enticements of bawds and the "wryting of loving sonets" (p.60) - a path which leads to public whipping in one case, to death in another. Gnomaticus observes that orderly training in the liberal arts is actually rather easy, and can lead to overconfidence in one's own wit; moral education is more difficult (p. 68). The play 
suggests that methods of teaching that favour ease over rigour, form over content, will leave a void which quick-witted minds will seek to fill with dangerously pleasurable pastimes. The skepticism about method voiced in The Glasse and in "Gascoignes Wodmanship" is familiar from Certayne notes of Instruction, where emphasis on the accidents of writing is accompanied by Gascoigne's studied refusal to order his poetic precepts in a methodical way. Despite the fact that this text has been included in a printed book and could easily have been better edited prior to typesetting, Gascoigne twice apologises for the "preposterous order" (pp. 455, 461) of his notes, and ostentatiously adds a comment at the end which he should have included earlier. Accident besets the way in which poetic art is presented as well as the content and practice of that art.

Elsewhere, however, Gascoigne seems willing to explore the possibility that poetic art might after all be susceptible to method. In his last work, The Grief of Joye, a collection of elegies presented in manuscript to Queen Elizabeth in 1576, Gascoigne depicts composition as a coolheaded arrangement of moral matter:

Towching the Methode and Invention, even as Petrark in his workes De remediis utriusque fortunx, dothe recoûpt the uncertaine Joyes of men in severall dialogues, so have I in thes Elegies distributed the same into sundrie songes. ${ }^{19}$

Here "methode" is both the process by which Gascoigne has compiled the work and the textual structure by which it might educate its reader; these two senses are always closely related in the period. ${ }^{20}$ Similarly, in the prefatory letter "To the reverende Divines" in the Posies of 1575, 
Gascoigne explains his revision and republication of A Hundreth Sundrie Flowres by asserting that

although I have bin heretofore contented to suffer the publication thereof, only to the ende men might see my Methode and maner of writing: yet am I nowe thus desirous to set it forth eftsoones, to the ende all men might see the reformation of my minde (p. 363).

For the rhetorical purpose of this letter, Gascoigne is willing both to claim that he possesses and deploys a "Methode," and to use a language of "ends," conceiving his mode of address to his literary public as deliberate and purposeful. This plainly contradicts another statement in the same letter, which paints publication as something far more contingent, improvisational or opportunistic:

if I were so desirous to have my capacitie knowne, I shoulde have done much better to have travelled in some notorious peece of worke, which might generally have spred my commendation. The which I confesse. But yet is it true that I must take the Foord as I finde it: Sometimes not as I woulde, but as I may (p. 363).

This attempt to have his cake and eat it, to avow and disavow statements and attitudes about his own artfulness in almost the same breath, quickly becomes familiar to readers of Gascoigne. In another prefatory letter to the Posies, he writes that "I terme some Floures, bycause being indeed invented upon a verie light occasion, they have yet in them (in my judgement) some rare 
invention and Methode before not commonly used" (p. 367). In this case, "Methode" refers more to the rhetorical stratagem of the poems (that is, to their capacity to surprise, please and teach their readers) than to the process of their composition. Although these works are methodical, their method is not staid or dutiful but "rare," reflecting well on their author despite the contingency of their origins. Gascoigne manages, in these instances, to occupy a shifting yet fertile middle ground, laying claim to just enough method to win him authority and to just enough daring opportunism to elicit admiration.

The confidence audible at these moments is at odds with what Jonathan Crewe has described as Gascoigne's "poetics of failure," an apt yet not exhaustive characterisation of his lyric persona. ${ }^{21}$ "Gascoignes Wodmanship" is indeed remarkable for the extent to which it displays its author's moral and practical shortcomings before fashioning a new, wiser and more nuanced sense of his character from the ruins of apparent humiliation. The poem is about both Gascoigne's practical skill and the wider issue of his virtue, the general state or settled disposition which precedes and determines his worldly actions. The Aristotelian ethical tradition which, as we have already seen, is operative in Gascoigne's poem offers (especially in the third book of the Nicomachean Ethics) fine distinctions between different states of deliberation, choice, volition, and control over one's actions and their results. Only voluntary actions are worthy of praise or censure; but the voluntary and the involuntary can be hard to distinguish, since many acts are in fact a composite of deliberation and circumstantial exigency. ${ }^{22}$ In the fifth book's discussion of justice and culpability we find three main degrees of responsibility for an inflicted injury, ranging from wrong done deliberately or passionately (adikēma) to pure accident or misadventure (atuchèma), the middle ground being occupied by 
various shades of hamartia, a word whose sense notoriously ranges between error, failure, fault, and the diverse degrees of awareness and intention therein implied. ${ }^{23}$ The same distinction appears in Aristotle's Rhetoric. ${ }^{24}$ In that text's discussion of epideictic rhetoric, we are advised that in praising a man we should amass examples of his worthy actions, even assuming that accidents ( $t a$ apo tuchess) are evidence of virtue. ${ }^{25}$ One might therefore assume that in "Gascoignes Wodmanship," which is in some respects an epideictic piece concerned with praise and blame, the consistent falling awry of Gascoigne's arrows amounts to damning evidence of his culpability. In Aristotle's discussion of forensic rhetoric-that is, of arguments for prosecution and defence, which are also at play in Gascoigne's poem - a distinction is drawn between things that happen through chance $(t u c h \bar{e})$ and those that happen through nature (phusis). ${ }^{26}$ "Gascoignes Wodmanship" attempts to show that these two things are not separable but intertwined, so that Gascoigne can without contradiction admit "fault" and blame that fault on "happe" (p. 313, 72.6-8). The poem's achievement is one of ethical nuance and capaciousness; it can encompass both the contingencies of the external world and the ambiguities of Gascoigne's striving for the consistency and stability of skill and virtue. Paul Alpers notes that Gascoigne's description of his avoidance of self-enriching acts of plunder during his time as a soldier, which might in one sense reflect well on Gascoigne's moral ethos, is in fact ambiguous: "it is difficult to tell whether his failure to act is a genuine moral refusal or a behavioral incapacity." 27 Such finely tuned moments of indeterminacy are typical of the poem's refusal to condone one-dimensional ethical judgement.

“Gascoignes Wodmanship" closes with the lines “Thus have I tolde my Lorde, (God graunt in season) / A tedious tale in rime, but little reason" (p. 316, 72.149-50). This is in several 
ways a weak ending - formally, in its feminine rhyme; and argumentatively, as it surrenders petition for prayer, agency for humility. The question of Gascoigne's reason has, of course, been asked throughout the poem: that he can rhyme proficiently and profusely is certain; that he can think concertedly and consistently less so. And yet there is also strength here: to rhyme even in the act of slighting rhyme cannot but be a joke; and to offer a feminine rhyme in a poem about arrows falling short of their mark is an amusing irony, bringing the poem to an end with a single, ethically and experientially complex vision of simultaneous strength and weakness, failure and success, abruption and closure. ${ }^{28}$ The closing couplet harnesses the poem's nuanced discussion about artfulness and virtue for reflection on poetics, as the act of writing itself is distanced from any simple notion of rational intention and placed instead under the control of rhyme, whose exigencies and effects are (as Gascoigne's Certayne notes would acknowledge) not wholly subject to the poet's agency.

In placing "Gascoignes Wodmanship" next to some of the standard philosophical texts read widely at the time, or to an analogue and possible source like Ascham's Toxophilus, I do not mean to suggest that those texts are simply used by Gascoigne to prove a point, or that we can use them as a mere gloss or key. Rather, they help us to see the nuance and complexity of which Gascoigne is capable, a necessary caveat to the widespread tendency to see him as a rhymer rather than a poet (and thus less worthy than others of our interest), or to understand his works merely as bids for prestige and patronage: such they may be, but they are more than that. ${ }^{29}$ The persistent critical interest in Gascoigne, which has only accelerated in recent years thanks to the work of scholars like Robert Maslen, Gillian Austen and Catherine Bates, has frequently focussed on issues of courtliness, masculinity, and self-fashioning. One notable exception is the 
work of Lorna Hutson (largely on Gascoigne's plays), which reveals his debts to contemporary legal culture: the next section of this essay is indebted to Hutson's exemplary exposition of the interrelations of legal, humanistic and literary discourses in Gascoigne's period. ${ }^{30}$ In some senses such work represents a return to a Gascoigne which recent accounts have somewhat obscured: the learned, or at least semi-learned, Erasmian Gascoigne compellingly described by Arthur Kinney. ${ }^{31}$ There remains a need for greater recognition of the scope of Gascoigne's seriousness as a thinker about his art, a seriousness which he may often try to hide but which is often well-informed and scrupulous. Writing without a significant tradition of English poetics behind him (though informed to some extent by continental rhetoric), Gascoigne fashions a powerful account of the nature and limitations of his skill, both in his brief attempt at theory and in his own poetic practice.

III

"Gascoignes Wodmanship" falls among the "devises of sundrie gentlemen" in the latter part of A Hundreth Sundrie Flowres. This section of the book acknowledges one group of poems as Gascoigne's, while other groups, linked together by the mottos or posies appended to each poem, are spuriously assigned to other poets. Before this section are three items: Supposes, a translation of Ariosto's comedy I suppositi; Jocasta, a translation by Gascoigne and Francis Kinwelmersh of Lodovico Dolce's Giocasta (a 1549 translation of Euripides' Phoenissae); and The Adventures of Master F.J., an original prose narrative interspersed with poems. All of these works are deeply concerned with questions of causality and accident. 
At the beginning of the volume, in Supposes, the play's heroine Polynesta explains to her nurse Balia the details of her love affair with Erostrato, who has disguised himself as his own servant, Dulippo. This expository dialogue establishes central lexical tendencies of the play, and formulates hermeneutic concerns posed throughout the Flowres as a whole. Balia, confused by Polynesta's account, says: "this geare is Greeke to me, either it hangs not well togither, or I am very dull of understanding" (1.1.60-62). In these lines Gascoigne is amplifying his Ariostan source. ${ }^{32}$ With such lexical choices the play fleshes out a particularly material poetics, presenting its own plot as a collection of physical "geare" which its characters must interpret, according to an epistemological criterion of coherence or "hanging together." 33 The term "geare," used in this way, is not uncommon in the writing of the period, but it is used with particular concentration in Supposes. ${ }^{34}$ Not only does it enable Gascoigne to figure the play's events as physical objects, but this metaphorical physicality means that "geare" becomes associated with the verb "to fall"; an occurrence or event is commonly described as something that "falls out." Dulippo remarks of the play's evolving intrigue: “This geare hath had no evill beginning, if it continue so and fall to happie ende" (2.3.1-2). Later, Erostrato's father Philogano asks his servant Litio, "how likest thou this geere?"; Litio replies, "I like it as evill as may be, but have you not often heard tell of the falsehood of Ferrara, and now may you see, it falleth out accordingly" (4.6.1-4). These characters know that they inhabit a world of accident, acknowledging its contingency and hoping to overcome it through the cautious and judicious prediction and interpretation of events.

This language of "falling" is not unique to Supposes. Throughout A Hundreth Sundrie Flowres we repeatedly encounter a range of related terms: "case," derived from the Latin casus 
("falling"), and "occasion," from the Latin occidere ("to fall down"), are the most common. The opening letter from the printer, who offers his "conjecture" about the uncertain "case" of the volume's production, is merely the first of many instances of such vocabulary (p. 3): while "accident" appears only once in the volume, "occasion" appears throughout, as the circumstances in which each item in the book was composed or performed are described. The "divers discourses and verses" which occupy the second half of the Flowres are "invented uppon sundrie occasions, by sundrie gentlemen" (pp. 141-42). G.T., the supposed editor of these poems, stresses that it is the quality of each poem when "considered by the very proper occasion whereuppon it was written" which prompted him to "gather them into some order" (p. 145). "Case" appears even more frequently, with a wider semantic range. In Supposes, it is used to describe the state of events or plot in general and, more specifically, the situation in which individuals stand at particulars points; both senses depend partly on the word's legal connotations $(1.1 .80,2.1 .106,5.5 .53,5.7 .39,1.3 .17,2.2 .15)$. At the beginning of Jocasta this second sense of "case," pertaining to the individual's current situation, comes to the fore: Jocasta laments her situation in front of her servant, who will, she thinks, "mone [her] mourning case" (1.1.15). In Master F.J., too, a "case" is something to be "lamented," "bewailed," or "pleaded"; a particular situation in which someone finds themselves; and a state of affairs (pp. 157, 159, 211, 174, 207-8). The particular cases - normally amatory affairs-described by the anthology's poems register all these conceptual possibilities: often caused by accident, they are also occasions for writing and particular cases for judgement (often in a legalistic sense). A further iteration of the language of occasion comes when the editor G.T. argues that even "in pleasaunt ditties or compendious Sonets... the most frosty bearded Philosopher, maye take just occasion of 
honest recreation" (p.143): these poems are also, therefore, occasions for hermeneutic and aesthetic response.

There is an almost programmatic regularity to the way in which Gascoigne's anthology posits the fact of worldly contingency as the context for various kinds of interpretation and judgement. Supposes and Jocasta, for instance, are in many ways companion pieces; both were originally performed at Gray's Inn in 1566, long before their print-publication, and from their different generic standpoints they negotiate many of the same questions using a shared vocabulary. The happy resolution of Supposes provokes the confident assertion "that not so muche as a leafe falleth from the tree, withoute the ordynance of god" (5.8.13-14); this phrase is precisely but mockingly echoed in Jocasta, a play which lacks such metaphysical confidence (3.3.34-40). Together the plays stage a debate about the extent to which the stochastic uncertainty of the individual act of falling may be subsumed within a larger, sense-making structure (in this case, providence). Both plays are concerned with the hermeneutic longing to make sense of a world where meaning does not exist as a totality to be grasped in advance of events but must be glimpsed in the midst of the action. In Jocasta Eteocles bemoans the unpredictability of events to Creon, saying: "other ende than I doe thinke may fall" (2.2.95). Aware that "occasion" may "slip out of [his] handes" (2.2.90), he seeks out the prophet Tiresias in order to satisfy a deep desire for certainty:

Yet longs my lingring mynde to understande

The doubtfull ende of this unhappie warre (2.2.110-111). 
In Supposes, Dulippo and Erostrato find themselves in a similar and constantly shifting position of epistemological suspension. By contrast, in the parasite Pasiphilo the play does contain a character who grasps the totality of the action and so embodies the certainty whose absence is painfully felt by the other personae:

I finde the meanes so to handle the matter, that I am welcome to bothe. If the one see me talke with the other, I make him beleeve it is to harken newes in the furtherance of his cause, and thus I become a broker on both sides (1.3.22-27).

Pasiphilo imports into the play that fascination with sheer capability familiar from Gascoigne's poetics, in which the writer must find the appropriate way to respond to a particular occasion and is judged by his consistency and mastery of the particulars he must respond to and subsume within his invention.

Master F.J., too, is replete with the language of chance, occasion and conjecture; and here too it accompanies an intense interest in the exercise and limitations of human intelligence in response to events. In the following passage this terminology comes together in a particularly concentrated way:

The Dame (whether it were by sodain chaunge or of wonted custome) fell one day into a great bleeding at the nose. For which accident the said F.J. amongst other prety conceits, had a present remedy, wherby he tooke occasion... to worke his feate (p. 151). 
Here, Gascoigne makes an etymological joke, as the word "fell" leads suggestively to "accident," which in turn becomes "occasion." F.J.'s opportunism in turning a sudden event to his advantage becomes a kind of poetic re-writing of "accident" as "occasion," a minor etymological shift which registers his agency at this point in the story. Master F.J. presents many instances of such "sodain chaunge." F.J. is often "taken uppon the sodeyne" (p. 154) by the two threateningly eloquent women of the house at which he is staying. ${ }^{35} \mathrm{He}$ commonly finds himself unable to answer with the prompt wit that his situation requires, comically failing to meet the standards which Gascoigne's Certayne notes of Instruction lay down for the inventing poet, who must endow his works with "some good and fine devise, shewing the quicke capacitie of a writer" (p. 454). Indeed, Gascoigne himself was praised by E.K. for his "wit and naturall promptnesse" in Spenser's Shepheardes Calender; and it is clear that in Master F.J. he creatively explores aspects of his own poetic persona, which relied extensively on the performance of spontaneous composition in response to sudden circumstance. ${ }^{36}$ The records of the entertainments at the Earl of Leicester's Kenilworth Castle in 1575 note that certain verses performed before Queen Elizabeth "were devised, penned, and pronounced" by Gascoigne "upon a very great sudden." But here, too, Gascoigne acknowledges that sudden phenomena can have a perturbing effect upon one's knowledge of the world and the self: he is reported to have told the Queen that he has "seene in heaven ... two such wonderfull changes as drawe [him] into deepe admiration and suddayne perplexitie." ${ }^{37}$ Likewise, in The Glasse of Governement, Phylautus comments that "the sodaine of [his] departure seemeth somewhat straunge" (p. 63). In both cases, a sudden event causes a temporary epistemological disorientation. This fits into an emerging picture of Gascoigne's preoccupations: he was a writer 
deeply interested in human judgement, in interpretation, in sense-making, and in the complexities which militate against these things. As in John Donne's third satire, "suddennes" - massy, messy, material suddenness - "resists." 38 In The Glasse, it is the same disreputable characters who talk of manipulating the play's "geare" who embrace the idea of acting suddenly and occasionally: the parasite Eccho is proud of his "cleanely shifte upon the sodeyne" because it allows him to "take occasion" to exploit Phylautus and Phylosarchus (p. 39). Across Gascoigne's works we find countless iterations and variations of these same vocabularies and ethical imperatives.

Gascoigne's sense of the seriousness of the sudden within the ethical realm of practical, lived experience-its challenge to intentionality, its generation of uncertainty and its demand to be understood - might partly be attributed to the concept's role in English law, particularly in distinguishing culpable murder from manslaughter. A manuscript note submitted to the Privy Council in 1572 records various "obiections why George Gascoigne oughte not to be admitted to be a Burgesse of the Parliament," among which he is said to be "noted... for manslaughter"; the truth of the accusation is uncertain..$^{39}$ The legal definition of manslaughter relied on terms like "chaunce medley" or the Latin phrase "ex subito casu," to distinguish spontaneous from premeditated killings. ${ }^{40}$ Without committing to any biographical determinism, one may note that the plots of Master F.J., Jocasta and Supposes, as well as the sundry events which have occasioned the "devises of sundrie gentlemen," are all complexes of such sudden cases or "fallings out"; while those plots do not involve manslaughter, their various suddennesses and accidents point to a number of interactions with the law, and with various kinds of legal reasoning in particular. Thanks to Joel Altman and Lorna Hutson, the legal engagements of 
Gascoigne's plays are now widely recognised; but critics have not extended this to the Flowres as a whole. ${ }^{41}$ The whole volume engages and explores processes of reasoning learned from the law and from the rhetorical and dialectical culture which surrounded it. In Ariosto's I suppositi, the terminology of supposition tends to denote the replacement of one person by another; but in Gascoigne's Supposes, a "suppose" is most commonly what Latin calls a suppositio and Greek a hupothesis. ${ }^{42}$ In the classical tradition of writers like Hermogenes and Quintilian, a hypothesis is a rhetorical or dialectical inquiry into a specific state of affairs or case, stimulating "definite" questions about a particular set of things, persons, times and other occasional contingencies ("ex complexu rerum, personarum, temporum, ceterorumque" $) .43$ In an even wider sense, we can see Gascoigne engaging with a casuistic tradition with diverse roots in law, theology and ethics. While Gascoigne predates the burgeoning of English casuistry inaugurated by William Perkins in the 1590s, casuistic methods are manifest in the way the Flowres' sundry devices offer the reader a selection of specific cases for judgement. ${ }^{44}$ Indeed, F.J. is twice made to participate in a casuistic exercise or quaestio, and is given the role of deciding "lytigious causes." Elinor and Fraunces call him the "moderator of these matters, and collector of these causes," equating judgement with the very act of collection (p. 191). This is one of many instances in the volume which scrutinise the process of reasoned judgement.

Casuistic discourse was especially prominent in one area of early modern public life to which, I suggest, Gascoigne alludes: the equity jurisdiction of the Court of Chancery. ${ }^{45}$ Equity is a simple concept with complex implications. In Gascoigne's period, it was variously identified with the spirit of justice underpinning all law, and with the way in which a judge in Chancery might lessen the harsh rigour of the law by taking into account all the particulars of a case. The 
locus classicus for this idea is Aristotle's recognition that one cannot set down universal principles which will be correct in all particular cases; accordingly he outlines a theory of epieikeia, normally rendered in Latin as aequitas, to resolve the disjuncture between abstract laws and specific problems. ${ }^{46}$ Equity both corrects the law and recovers the just intention that lies behind it. Its general applicability was asserted by the legal theorist Christopher St German in the 1530s in his maxim that "Lawes couet to be rewlyd by equytye." Equity's necessity is born of the fact that "the dedes and actes of men... happen in dyuers maners infynytlye," meaning that judging them is both hermeneutically and ethically challenging. ${ }^{47}$ Underpinning both early modern ethical casuistry and the legal reasoning of the equity jurisdiction of Chancery was the idea of the conscience of the judge, understood in favourable accounts as a fundamentally rational principle. ${ }^{48}$ It was the Chancellor's role to follow conscience in assessing the full complexity and particularity of each case. For some writers, the rationality of conscience could be described syllogistically: a general moral rule functions as the major premise of a syllogism, and particular cases as minor premises; in turn, the conscience must assent to or deny the validity of the minor premise and produce a syllogistic conclusion. ${ }^{49}$ However, even St German, who writes in favour of the role of conscience and reason in legal judgement, is aware of potential problems with this process:

the cause why conscyence maye so erre in the sayd case \& in other lyke is bycause conscyence is formed of a certayne partyculer proposycyon or questyon groundyd vpon vnyuersall rewles ordayned for such thynges as are to be done. And bycause a partyculer proposycyon is not knowen of hym selfe... but must appere and be serchyd 
by... a dylygent serche of reason/ therfore in that serche and in the conscyence that shuld be formed therupon may happen to be erroure... whiche errour commeth eyther bycause he dothe not assent to that he ought to assent vnto/ or els bycause his reason wherby he dothe... referre one thynge to another is dysceyued (p. 91).

St German admits the flaws found in human reasoning, and describes one potential source of this failure in the difficulty of rightly relating one thing to another.

Gascoigne was aware of the difficulty and dialectical complexity of such legal judgement. These concepts come into play at several important moments in Gascoigne's Flowres. Both of the volume's plays and some of its poems present characters seeking redress for grievances, appealing for equitable judgement. In "Gascoignes libell of Divorce," one of several explicitly legalistic poems, the speaker asks the figure of death to "judge" his "cause": "Consider every circumstance, marke how the case doth stande" (p. 270, 54.29-30). This request invokes a kind of equity: the sixteenth-century Chancery could take all the facts of the case into account, something which the strict processes of the common law courts did not always allow. A similar depiction of a case as a complex set of facts demanding judgement comes in Supposes, when Philogano exclaims: "Bring me then to the Judges, to the potestates, or to whome you thinke best: for I will disclose a packe of the greatest knaverie, a fardell of the fowlest falsehoode that ever was heard of" (4.8.38-40). A reader of Gascoigne's miscellany may notice that the case itself is depicted as a collection or bundle of particulars, not unlike the book in his own hands.

Gascoigne's most extensive engagement with equity comes in the agon between Polynices and Eteocles in Jocasta. Polynices makes a speech full of appeals to the "rule" of an 
implicitly universal and natural "reason" (2.1.323) in his quasi-legal quest for "equall doome" (2.1.327). The Chorus agrees that Polynices has spoken honestly and justly, but Eteocles refutes this:

If what to some seemes honest, good and just,

Could seeme even so in every doubtfull mind,

No darke debate nor quarell could arise:

But looke, how many men so many minds,

And that, that one man judgeth good and just,

Some other deemes as deepely to be wrong.

To say the truth (mother) this minde of mine

Doth fleete full farre from that farfetch of his (2.1.350-57).

The phrase "how many men so many minds" recalls the contemporary jurisdictional struggle between the common law courts and the court of Chancery. The preeminent landmark in this debate was Christopher St German's Doctor and Student (although the struggle persisted well into the seventeenth century). One manuscript text responding to Doctor and Student rehearses a defence of the common law courts of King's Bench and Common Pleas against the creeping jurisdiction of Chancery, giving the same reason as Eteocles against any basing of legal judgment in conscience: "divers men, divers conscience." ${ }^{50}$ Such diversity would render justice mutable and vulnerable, its outcomes dangerously unpredictable. The variety of human minds 
is seen, in this account, as an agent of hermeneutic accident, undermining the artful control over the events of human society which the law is supposed to provide.

It is clear, then, that throughout Gascoigne's work the same issues which pervade his poetics and his self-presentation in "Gascoignes Wodmanship" are woven into the fabric of his fictions. At the centre of his oeuvre is the ever-present encounter between the individual agent and a world conceived as sundry, chaotic, and resistant to interpretation. In constructing fictional texts on the basis of accidents and occasions, Gascoigne introduces into his work a philosophically destabilising principle, radically indeterminate in its effect, problematically connected to intention, and charged with ethical uncertainty. ${ }^{51}$ Gascoigne brings into play questions of method and judgement derived from the law and from the humanist pedagogy of rhetoric and dialectic; but he always looks beyond theory towards the infinitely complex realm of practice, testing the link between rational judgement and practical action. Suddenness may be disorientating, but it demands response; occasions may be dangerous, but they demand action; gear may be chaotic, but it demands the discernment of coherence; cases may be complex, but they demand judgement.

This link between accident and interpretation engages with widespread contemporary theories and practices of reading. Aristotle had said that there was no certain knowledge of the accidental; $; 2$ but readers in Gascoigne's day were primed to discern patterns and attempt to impose method and order upon the particulars of the literary material they encountered. Thomas Blundeville's prescriptions for reading and writing histories attempt to remove the epistemological uncertainty of accidents by taxonomising them according to their causes, to produce the kind of stable knowledge of them which Aristotle had thought impossible: 
And bycause we finde manye tymes, that like meanes haue bene vsed to the obtayning of like endes, (as we suppose) \& yet not with like successe, we ought therfore diligently to consider the diuers natures of thinges, and the differences of tymes, and occasions, and such like accidents, to see if we can possibly finde out the cause why mens purposes haue taken effect at one time, and not at an other. And by noting all that hath bene sayde, touching the nature and propertie of anye thing, we shall learne which accidentes are woont to accompanie togither and which not. ${ }^{53}$

In the final section of this essay I shall suggest that while Gascoigne entertains a similar mode of reading for his own work, agreeing with Blundeville that hermeneutic effort is required in the face of the accidental, he is far more daring in his embrace of contingency, incorporating it into the very fabric of the book with which he began his career as a writer in print.

IV

When Supposes, Jocasta, Master F.J. and the "devises of sundry gentlemen" came to be printed in 1573, texts which were already deeply concerned with accident came together in a book whose own production and bibliographical details are complex and chaotic. In the final section of this article I want to suggest that Gascoigne's sense of the accidental is bound up, in sundry ways, with the way in which the binding up of the sundry in a single book makes provocative if 
precarious claims to unity, foregrounding for the reader the same questions which Gascoigne asks in his fictions and in reflecting on his own poetic practice.

A Hundreth sundrie Flowres bound vp in one small Poesie has long been noted for “bibliographical eccentricities which it seems hopeless to explain." ${ }^{44}$ A quarto gathered in fours, collating $\mathrm{A}^{4} \mathrm{~B}^{4}(-\mathrm{B} 1,2) \mathrm{C}-\mathrm{X}^{4},{ }^{2} \mathrm{~A}-\mathrm{Y}^{4} \mathrm{Aa}-\mathrm{Ii}^{4}$, among its oddities are: the cancellation of leaves $\mathrm{B} 1$ and B2, signalling that gathering A was among the last to be printed; jumps in pagination from pages $36(\mathrm{~F} 4 \mathrm{v})$ to $45(\mathrm{G} 1 \mathrm{r})$ and from pages $164(\mathrm{X} 4 \mathrm{v})$ to 201 (2A1r); and variations in font. A close codicological analysis, based on conjectural accounts of printing house practices and an examination of the different states of the fonts throughout the volume, enabled Adrian Weiss to construct a detailed (though provisional) narrative of the volume's production. ${ }^{55}$ Weiss supposes that Henry Bynneman printed gatherings B to X in January and February of 1572/3, having been given the job by the publisher Richard Smith. These gatherings contain Supposes and Jocasta, which Smith and Bynneman originally believed to represent a discrete book; but Gascoigne himself halted publication, intending to add Master F.J. and the "devises of sundry gentlemen," parts of which were delivered to the printer in May 1573 but passed to Henry Middleton during a busy period for Bynneman's workshop. This was not an instance of shared printing of the common kind designed to expedite publication. By this point in the year Bynneman knew that another text was to be included after Jocasta but before F.J.; his casting-off led him to allot pages 165 to 200 for this work, which did not ultimately appear. Weiss hypothesises that this was to be Dan Bartholomew of Bathe, and that Gascoigne's failure to complete this sequence of poems - which was printed in its incomplete state at the end of the Flowres, only to be published in full in the 1575 Posies - caused the gap in pagination. Middleton 
printed gatherings ${ }^{2} \mathrm{~A}$ to ${ }^{2} \mathrm{~S}$, beginning at page 201 , a section which may have been delayed by Gascoigne's protracted writing of the text and the delivery of Master F.J. and the "Devises" to Middleton in "two manuscripts without any explanation of their textual relationship." Weiss believes that Bynneman printed the rest of the book piecemeal between May and August, with gathering A printed last. In sum, Weiss suggests that printing took place sporadically over eight months, that copy was delivered in "at least six separate manuscript segments," that the complex fictional frame evolved during this period, and that Gascoigne (who was in Holland for at least some of this time) was not involved in printing or proofing. ${ }^{56}$

This catalogue of unintended consequences means that the book's final form must be seen as accidental; no one individual's intentions for the book seem to have been fully realised. This is only further exaggerated by the book's fictional frame of multiple authorship and editorship. The opening epistle to the reader refers to a letter written by H.W. "in the beginning of this worke" (p. 3), but H.W.'s letter does not appear until after Jocasta. H.W.'s letter, in turn, logically precedes G.T.'s first letter, which logically precedes The Adventures of Master F.J., so it appears that Gascoigne believed that Master F.J. would open the volume. While the metaphors of the book's title impart a kind of unity, asserting that its sundry items constitute “one small Poesie," the oddities which prompted Weiss's analysis were of course in plain view for an early modern reader, leaving this putative unity provisional and open to doubt. Curiosity - or, indeed, frustration - is further solicited by the introductory epistle, in which an unnamed printer says of the circumstances surrounding "the imprinting of this poeticall Poesie" that "the case seemeth doubtful," and that he will "disclose [his] conjecture" about it (p. 3). As we have already seen, this is a lexis that will recur throughout the volume. The letter foregrounds the 
need and desire for conjecture, setting up a provocative uncertainty about the patterns of intention to which the book bears witness. It then constructs a complex narrative explaining how these texts came to be presented to the world in the bibliographically bizarre form of this book: H.W. and G.T. (initials which provoke more questions than they resolve) have acquired the manuscripts from which the book has been formed, and have effected their publication. Later, the printer's identity is given by H.W. in another paratextual letter as A.B (p. 142). However, after Jocasta, and just before this letter from H.W., an intermediate imprint - “Printed by Henrie Bynneman for Richarde Smith" - intimates that the printing of the book was more complicated than is made explicit. ${ }^{57}$ The sense that a series of agents have conspired to produce this chaotic state of affairs, with no guiding intelligence able to survey the whole process, deprives us of the looming, authorising presence of intention as a guarantor of the book's capacity, qua book, to mean. This is in some sense, then, an extreme instance of the condition that affects all miscellanies and anthologies, which are at once the result of choices made by editors and free spaces for an indeterminate number of possible acts of reading. What emerges from this complex state of affairs is a fortuitous collaboration between aspects of the book's material history and the conceptual preoccupations of its contents: both are suffused with a sense of the accidental and of the intentional - an intention sometimes deflected by accident, sometimes felicitously supported by it.

Despite the contingencies of its publication, A Hundreth Sundrie Flowres makes greater claims to wholeness than its main English models, which include Tottel's Songes and Sonettes and the single-author collections by Barnabe Googe (the Eglogs, Epytaphes, and Sonettes of 1563) and George Turberville (the Epitaphes, Epigrams, Songs and Sonets of 1567), whose titles merely 
describe their contents. In the Flowres, both the printer's letter to the reader and the title-page use the word "poesie" of the whole volume. In the title the term is primarily used to designate a bouquet; but it is difficult to see how a hundred flowers might form a "small" posy. Furthermore, "poesie" is orthographically indistinguishable from "poesy" in the sense of "poem," and gestures towards the idea of poiēsis: a "poesie" is a made object, the single product of a creative process. Indeed, the notion of binding found in the title is historically associated with philosophical ideas of "oneness": Aristotle wrote that some of the things we identify as unified objects are so called because they occupy a continuous space, giving the examples of bundles made one by a band and wooden objects made one by glue. ${ }^{58}$ Similar ontological questions pertain to the notion of the "hundreth," a vague predicate whose force does not depend on the actual existence of a hundred objects, but which argues more strongly for the unity of the volume than would a less "round" number, naming both an aggregation of monads and the whole which they form. In taunting its readers with the vexed question of its unity or multiplicity, A Hundreth Sundrie Flowres engaged with, and indeed contributed to, a midElizabethan fashion for anthologies which made claims to aesthetic wholeness or coherence. After the pioneering Songes and Sonettes collected and printed by Richard Tottel in 1557, a book whose title simply describes its contents, later verse miscellanies offer images of the spaces that contain, circumscribe and mediate their poems: The paradyse of daynty deuises (1576), A gorgious Gallery, of gallant Inuentions (1578), A Handefull of pleasant delites (1584), and Brittons bowre of Delights (1591) are just a few examples. By the time Shakespeare, in The Merry Wives of Windsor, alluded to Tottel's important collection, it had become a "book," no longer a bundle of particulars but a single object for use or manipulation by a reader: "I had rather than forty 
shillings I had my book of songs and sonnets here." ${ }^{59}$ Books of the period commonly recognise that something new could be created when disparate poetic pieces were collected together. In 1548, a young Theodore Beza (whose later metamorphosis into a Calvinist proselytiser would be a model for Gascoigne's own public moral reformation) published his amorous lyrics, describing the process of gathering them together as if to form a "corpus." 60 The "libellus" thus produced is itself the product of artistic making, and its coherence as a single object, its status as an entity, is in more than one sense "made up": it is both a fiction (something not quite real) and an artefact (something undeniably real). Gabriel Harvey, a noted reader and annotator of Gascoigne's Posies (his copy survives at the Bodleian Library), gives us reason to think that contemporary writers were aware of the potential for literary subtlety and meaning in the order and arrangement of such books: in his own rough literary notes, he fantasises about the publication of "younge Conceytes, and poeticall Deuises," gathered to form a "Treatise" containing "all the Poeticall Deuises, that euer I made in Inglishe/ sett in as witty, \& fine order, as may be." 61

Following the lead of such early modern accounts, recent literary scholarship has found it a natural critical impulse to think of anthologies of various types and provenances as whole objects, always in some way greater than the sums of their parts. ${ }^{62}$ To think of a miscellany or anthology in this way is a central demand of the turn towards "material textuality" so important in recent literary scholarship. Don McKenzie's seminal Bibliography and the Sociology of Texts (1986) taught us that the complexities of the material book, including the juxtaposition of texts in a single volume, should be of immediate and unavoidable importance to any critic blithely hunting for meaning. Rather than understand meaning as a logical structure present in 
the book, a "material" hermeneutics understands the book as a place of encounter in which different kinds of reading may occur on different occasions, where meaning is not logically fixed but fluid and potential, awaiting the contingent circumstances in which it might be realised, and subject to a range of worldly contexts, interruptions and constraints.

It is important to recognise that any sense of "material textuality" in Gascoigne's period itself would have been expressible and comprehensible partly in terms of the long-standing philosophical interest in accident and contingency which I have already described. In the Aristotelian tradition accidents are often understood as (in Michael Witmore's gloss) "the result of an unexpected meeting of independent causal chains." ${ }^{63}$ This, of course, is a good way of describing the kind of interactions between texts to which a miscellany or anthology can play host. The freedom in anthologies to read non-sequentially, selecting or fortuitously encountering particular poems, enables unrelated objects to come into contact with each other, creating unintended and unpredictable but nevertheless meaning-laden structures. Gascoigne describes this very process in one poem in the Flowres. "Gascoignes councell to Douglasse Dive" is a piece which explicitly confronts the issue of what happens to a poem when introduced to a collection in which it doesn't quite belong; he notes that "To binde a bushe of thornes amongst swete smelling floures / May make the posie seeme the worse," and "feare[s] to finde like fall" if his own words are introduced to Douglasse's manuscript miscellany (p. 293, 68.1-2, 7). Not only does this concede the principle of hermeneutic relativity and accident; but it contributes to the sense that hidden in each of the Flowres' poems lies an allegory for the reading of the book itself. We have already seen that "Gascoignes Wodmanship" embodies concerns which resound throughout his work; the same could be said of poems like "Gascoignes Gardnings," which 
compares the world to a garden full of sundry flowers which "fall sundrye wayes" (p. 317, 73.36), or "Gascoigns Anatomie" (pp. 263-64, 49), which itemises its speaker and so asks questions about the relation of the part to the whole which pertain to the book in which it is printed. Any one of these poems seems to offer an allegorical key to the book; but in fact they merely allegorise the interpretive process itself.

A Hundreth Sundrie Flowres thus asks us to entertain the possibility that hidden within its accidental state there might be one or more coherent narratives, patterns or orders-if only we could find them. G.T. tells H.W. that when he had "with long travayle confusedly gathered together" the works in the book, he "thought it then Opere precium, to reduce them into some good order" (p. 144). ${ }^{64}$ This process of ordering is based on authorship: "as neare as I could gesse, I have set in the first places those which Master F.J. did compyle" (p. 145). As we have already observed, Master F.J. is not, as it was apparently meant to be, placed first in the book: readers are forced to notice that order is a desideratum offered but unfulfilled. Master F.J. itself contains several images of textual ordering and disorder: F.J. reassembles a letter from Elinor which he has torn up, "placing all the peeces therof, as orderly as he could" (p. 147); and he gives her three interconnected sonnets, having "sorted this sequence" (p. 151). The book emphasises the materiality of reading and writing, locating in that materiality the reason for its failures of order. Indeed, in reading F.J.'s sequence Elinor is said to have "turned over and retossed every card" (p. 153): her engagement with the text is a physical and energetic one, which potentially works against F.J.'s careful sorting. The scene of textual encounter imagined within A Hundreth Sundrie Flowres is one in which readers impose order on the chaotic matter of 
reading; that order is both a necessary source of hermeneutic stability and something subject to accident.

$\mathrm{V}$

As Gascoigne entered the world of print in 1572-1573, he did so in a book in which the potential for accidents of reading is multiplied and questions of intention are muddied. Accident and occasion, which for Gascoigne are always inescapable elements of the creative process, are also embedded in the process of publication and, in turn, in the reading of the book. The printer's prefatory letter talks of defending the Flowres from "any such misliking, as the graver sort of greyheared judgers might (perhaps) conceive": judgement is not here an abstract question of logical rectitude, but something which involves the contingencies of the will. The letter comments, further, that "nothing is so wel handled now adayes, but that some malicious minds may... take occasion to mislike it," but also that "the well minded man may reape some commoditie out of the most frivolous works" (p. 3). This contingency is further emphasised, and the book's audience further fragmented, when the letter says: "thus muche I have thought good to say in excuse of some savours, which may perchance smell unpleasantly to some noses, in some part of this poeticall poesie" (p. 4). The language of contingency with which Gascoigne and his publishers sought to describe the book's reception is not one born of any great theory of human mutability or sin or metaphysical chaos, merely of a more local and worldly sense of the pragmatic immediacy of experience. This eschews any language of profound aesthetic 
achievement, or indeed any overarching philosophic or didactic purpose, for something which is nevertheless rich and vital.

In his highly influential Poetices libri septem (1561), Julius Caesar Scaliger identified four key virtues that the poet must possess: prudentia, varietas, efficacia, suavitas. Of these, prudence is clearly the virtue most deeply connected to the poet's own ethical state. Scaliger describes it as a habit which derives all its deeds and utterances from reasons so that they fulfil their ends without incident ("habitum, qui deduceret omnia sua facta ac dicta e rationibus ad fines suos sine offensione"). He goes on to say that the prudent poet is one whose gaiety and exuberance, his gravity and humility, his courteousness and his lofty speeches, should be arranged in their proper place, time and manner ("cuius festiuitas, lasciuia, seueritas, humilitas, ciuilitas, magniloquentia... suo loco, tempore, modo dispositæ sint" $).{ }^{65}$ The process of writing is one of finding the right place for each attribute or part, both of the text created and of the self which creates. There is no evidence that Gascoigne knew Scaliger's work; but my reason for positing this description of the poet's prudence is to make clear both the similarity and difference of Gascoigne's own understanding of the logic of writing. "Gascoigns Anatomie," to which I have already alluded, has an explicit aim - “To make a lover knowne" -in pursuing which "every part shall play his part to paint the pangs of love"; the emaciated body parts Gascoigne describes "May stand for patterne of a ghost, where so this carkasse go" (p. 263, 49.1, 4, 10). These lines adumbrate a vision of writing which permeates the Flowres, in which literary texts bear witness to their creators, not simply by expressing opinions and making arguments, but by representing the states, habits or virtues which gave rise to them. Two years later, in the Certayne notes, Gascoigne would announce his modest intention "to set downe [his] simple 
skill" (p. 454) a skill which is then represented not as a single, rational, settled hierarchy of precepts, but as a bundle of ad hoc rules, guidelines and sleights-of-hand. Both these texts suggest that the poet's identity cannot be summed up as a simple, unitary substance, but is rather a collection of parts, an open and improvised rather than closed and permanent state of being. Gascoigne shares with Scaliger and other contemporary literary theorists an acknowledgement that writing is about forming those parts into a whole; but in his writing, his presentation of interpretation, and his foray into publication, Gascoigne eschews the cool rationality and calculating intention of a philosophical theorist like Scaliger in favour of the "quicke capacitie" of one who knew well the contingencies of the fall of an arrow.

\section{ST JOHN'S COLLEGE, OXFORD}

${ }^{1}$ Edmund Spenser, The Faerie Queene, ed. A.C. Hamilton, 2nd ed. (London, 2007), pp. 714-18.

${ }^{2}$ George Gascoigne, A Hundreth Sundrie Flowres, ed. G.W. Pigman III (Oxford, 2000), pp. 1-2. All quotations from A Hundreth Sundrie Flowres and from its revised version, The Posies (including Certayne notes of Instruction), are taken from this edition and are given parenthetically in the text. Plays are cited by act, scene, and line number; poems by page number, the number given to them by Pigman, and by line; and prose texts by page number.

${ }^{3}$ Yvor Winters was the principal modern champion of the poem: see his "The $16^{\text {th }}$ century lyric in England: a critical and historical reinterpretation: part 1," Poetry 53 (1939), 269-72.

${ }^{4}$ Aristotle, Nicomachean Ethics, 1106b36. I transliterate from the text in Aristotelis Ethica Nicomachea, ed. Ingram Bywater (Oxford, 1894).

${ }^{5}$ Roger Ascham, English Works, ed. William Aldis Wright (Cambridge, 1904), p. 1; Plato, Phaedrus, 246b-d. 
${ }^{6}$ Plato, Phaedrus, 260e5; Gorgias, 462b11-c2.

${ }^{7}$ Aristotle, Nicomachean Ethics, 1094a1-2; cf. 1139b1-2 on the telos of each separate art.

${ }^{8}$ Aristotle, Nicomachean Ethics, $11138 \mathrm{~b} 23$.

${ }_{9}^{9}$ Aristotle, Nicomachean Ethics, 1106b15-16, 1106b28, 1109a22-23.

${ }^{10}$ Aristotle, Posterior Analytics, 89b10-13. I transliterate from the text in Aristotelis Analytica Priora et Posteriora, ed. W.D. Ross (Oxford, 1964). Compare Nicomachean Ethics, $1142 \mathrm{b6}$.

11 Thomas M. Greene, “Roger Ascham: The perfect end of shooting,” English Literary History 36 (1969), 609.

${ }^{12}$ Jonathan Crewe, Trials of Authorship: Anterior Forms and Poetic Reconstruction from Wyatt to Shakespeare (Berkeley, 1990), pp. 130-31. Crewe's argument with respect to Gascoigne's debt to Ascham is approved and expanded in Catherine Bates, Masculinity and the Hunt: Wyatt to Spenser (Oxford, 2013), pp. 111-44 (esp. pp. 123, 126). In contrast, Richard Helgerson discerns many similarities of attitude between Ascham and Gascoigne, despite their apparent differences; see his The Elizabethan Prodigals (Berkeley, 1976), esp. pp. 53-57.

${ }^{13}$ E.K.'s gloss to Spenser's “November" eclogue deems Gascoigne "a wittie gentleman... who and if some partes of learning wanted not (albee it is well knowen he altogyther wanted not learning) no doubt would haue attayned to the excellencye of those famous Poets." Edmund Spenser, The Shorter Poems, ed. Richard McCabe (London, 1999), p. 146.

${ }^{14}$ See Aristotle, Nicomachean Ethics, 1140a18-20. On the relationship of tuchē and technē, see Martha Nussbaum, The Fragility of Goodness: Luck and Ethics in Greek Tragedy and Philosophy, 2nd ed. (Cambridge, 2001), pp. 94-95, 260-63.

${ }^{15}$ On the legal debate, see Richard Helgerson, Forms of Nationhood: The Elizabethan Writing of England (Chicago, 1992), pp. 65-104. On the fashion for method, see esp. Neal Gilbert, Renaissance Concepts of Method (New York, 1960). 
${ }^{16}$ See Sir Anthony Fitzherbert, The boke of iustices of peas (London, 1505), and La graunde abridgement (London, 1516). These and other works by Fitzherbert were frequently reprinted later in the century. Gascoigne's other legal reference here is to the Tenures, a late fifteenth-century treatise on land law by Sir Thomas Littleton, printed over ninety times in the sixteenth century.

${ }^{17}$ George Gascoigne, The Noble Arte of Venerie or Hunting (London, 1575), sig. A2v. On the authorship of this work, which was once attributed to George Turberville, see Jean Robertson, "George Gascoigne and The Noble Arte of Venerie and Hunting," Modern Language Review 37 (1942), 484-85.

${ }^{18}$ George Gascoigne, The Glasse of Governement, in Complete Works, ed. J.W. Cunliffe, 2 vols (Cambridge, 1907-10), II, pp. 1-90 (p. 16).

${ }^{19}$ George Gascoigne, The Grief of Joye, in Complete Works, II, pp. 511-57 (p. 514).

${ }^{20}$ The calm rationality of Gascoigne's poetics in this work mitigates its stress on the existential instability caused by the "manye perilles" and various "occurrents" of human life. Life is like "a flyeng chase, continuallie hunted withe Callamities": it is radically accidental, full of events and unintended consequences, best symbolised by the vulnerable animals who "oftentymes light in the nett or snare (unseene) whyles they flye to eschew the open mowthed hownde" (p. 513).

${ }^{21}$ Crewe, p. 125. Compare Robert Maslen, Elizabethan Fictions: Espionage, Counter-Espionage, and the Duplicity of Fiction in Early Elizabethan Prose Narratives (Oxford, 1997), pp. 114-57, on Gascoigne's "fiction of failure."

${ }^{22}$ Aristotle, Nicomachean Ethics, 1109b30-1114b25.

${ }^{23}$ Aristotle, Nicomachean Ethics, 1135b11-1136a9.

${ }^{24}$ Aristotle, Rhetoric, 1374b4-9. I transliterate from the text in Aristotelis Ars Rhetorica, ed. W.D. Ross (Oxford, 1959).

${ }^{25}$ Aristotle, Rhetoric, $1367 \mathrm{~b} 25$.

${ }^{26}$ Aristotle, Rhetoric, 1369a32-b1. 
${ }_{27}$ Paul Alpers, “Renaissance lyrics and their situations," New Literary History 38 (2007), 317.

${ }^{28}$ Compare the sympathetic reading of these lines in Alpers, 320-21.

${ }^{29}$ For an account which stresses Gascoigne's socio-economic rather than his intellectual or aesthetic interests, see Gillian Austen, George Gascoigne (Woodbridge, 2008).

${ }^{30}$ Lorna Hutson, The Invention of Suspicion: Law and Mimesis in Shakespeare and Renaissance Drama (Oxford, 2007), pp. 190-216.

${ }^{31}$ Arthur Kinney, Humanist Poetics: Thought, Rhetoric, and Fiction in Sixteenth-Century England (Amherst, 1986), pp. 89-117 (esp. pp. 97-98).

32 See Lodovico Ariosto, I suppositi (Venice, 1551), sig. A5r.

${ }^{33}$ Balia soon repeats the formula (1.1.103); it is also used in Master F.J. (p. 155).

${ }^{34} \mathrm{He}$ also uses the word a great deal in The Glasse of Governement: see pp. 35, 36, 38, 43, 65, 70, 76.

35 See also Gascoigne, A Hundreth, pp. 146-48, 151-52, 154, 157, 159, 161-62, 181, 183, 191, 198-200, 203, $205-$

6.

36 Spenser, Shorter Poems, p. 146.

${ }^{37}$ George Gascoigne, The Princely Pleasures at Kenelworth Castle, in Complete Works, II, pp. 102, 121.

${ }^{38}$ John Donne, "Satyre III," 1. 82, in The Satires, Epigrams and Verse Letters, ed. Wesley Milgate (Oxford, 1967), p. 13.

${ }^{39}$ National Archives, State Papers, 12/86, fol. 235r.

${ }^{40}$ See Luke Wilson, "Renaissance Tool Abuse and the Legal History of the Sudden," in Literature, Politics and Law in Renaissance England, ed. Erica Sheen and Lorna Hutson (Basingstoke, 2005), pp. 121-45.

${ }^{41}$ Joel Altman, The Tudor Play of Mind (Berkeley, 1978), pp. 158-61, 260-63; Hutson, Invention of Suspicion, pp. 190-207.

${ }^{42}$ For a detailed analysis of the role of the rhetorical and dialectical concept of hypothesis in literature, see Wesley Trimpi, Muses of One Mind: The Literary Analysis of Experience and its Continuity (Princeton, 1983). 
${ }^{43}$ Quintilian, Institutio oratoria, ed. and trans. H.E. Butler (London, 1921-22), I, p. 400 (3.5.7).

${ }^{44}$ On early modern casuistry, see especially Albert Jonsen and Stephen Toulmin, The Abuse of Casuistry: A History of Moral Reasoning (Berkeley, 1988) esp. pp. 152-71; and, for a more literary analysis, Lowell Gallagher, Medusa's Gaze: Casuistry and Conscience in the Renaissance (Stanford, 1991).

${ }^{45}$ For an overview of English equity in the period leading up to Gascoigne's time at Gray's Inn, see Sir John Baker, The Oxford History of the Laws of England, Volume VI: 1483-1558 (Oxford, 2003), pp. 40-49. See also Mark Fortier, The Culture of Equity in Early Modern England (Aldershot, 2005).

${ }^{46}$ Aristotle, Nicomachean Ethics, 1137b13-14.

${ }^{47}$ Christopher St German, Doctor and Student, ed. T.F.T. Plucknett and J.L. Barton (London, 1974), pp. 9597.

${ }^{48}$ On Chancery, see most recently Dennis Klinck, Conscience, Equity and the Court of Chancery in Early Modern England (Farnham, 2010). For the role of conscience in casuistry and in literature, see The Renaissance Conscience, ed. Harald Braun and Edward Vallance (Oxford, 2011), and Meg Lota Brown, Donne and the Politics of Conscience in Early Modern England (Leiden, 1995).

${ }^{49}$ St German, Doctor and Student, pp. 88-89.

${ }^{50}$ The Replication of a Serjeant at the Laws of England, in Christopher St. German on Chancery and Statute, ed. John Guy (London, 1985), p. 101. The Replication may have been written by St German himself, as a stalking horse for his own argument.

${ }^{51}$ On the role of the unexpected in early modern epistemology, see Jean Céard, La nature et les prodiges: L'insolite au XVIe siècle (Geneva, 1996).

52 Aristotle, Metaphysics, 1026b26-27. On the various concepts of the accidental in Aristotle, see Alban Urbanas, La notion d'accident chez Aristote (Montreal, 1988); and, more broadly, Ross Hamilton, Accident: A Philosophical and Literary History (Chicago, 2007). 
${ }_{53}$ Thomas Blundeville, The true order and Methode of wryting and reading Hystories (London, 1574), sig. H1r. See the discussion of Blundeville in Eugene Kintgen, Reading in Tudor England (Pittsburgh, 1996), pp. 14049, but note that Kintgen sometimes oversimplifies his subject, asserting for instance that "educated Tudors had only one way to talk about a literary text" (p. 89). More persuasive is John Kerrigan, "The Editor as Reader: Constructing Renaissance Texts', in The Practice and Representation of Writing in England, ed. James Raven, Helen Small and Naomi Tadmor (Cambridge, 1996), p. 114: “Renaissance authors knew that readers' responses could be as various as the readers themselves." Kerrigan discusses Gascoigne at length.

${ }^{54}$ Henry Plomer, “Henry Bynneman, Printer, 1566-83,” The Library 9 (1908), 236.

${ }^{55}$ Adrian Weiss, “Shared Printing, Printer's Copy, and the Text(s) of Gascoigne's A Hundreth Sundrie Flowres," Studies in Bibliography 45 (1992), 72-105. George Pigman questions elements of Weiss's account, but most of his analysis remains persuasive if not conclusive; see Gascoigne, A Hundreth, pp. liv-lxi. See also Austen, George Gascoigne, pp. 68-83.

56 Weiss, 95, 90, 97-99.

${ }^{57}$ George Gascoigne, A Hundreth Sundrie Flowres (London, 1573), sig. X4v (this imprint is not reproduced in Pigman's edition).

${ }^{58}$ Aristotle, Metaphysics, 1015b36-1016a2.

59 The Oxford Shakespeare: The Complete Works, ed. Stanley Wells, Gary Taylor et al., $2^{\text {nd }}$ ed. (Oxford, 2005), p. $514(1.1 .180-81)$.

${ }^{60}$ Theodore Beza, Poemata (Paris, 1548), sigs. a2r-v.

${ }^{61}$ BL Sloane MS 93, fol. 69v.

${ }^{62}$ See Anne Ferry, Tradition and the Individual Poem: An Inquiry into Anthologies (Stanford, 2001), and Neil Fraistat (ed.), Poems in their Place (Chapel Hill, 1986). 
${ }^{63}$ Michael Witmore, Culture of Accidents: Unexpected Knowledges in Early Modern England (Stanford, 2001), p. 27.

${ }^{64}$ This vocabulary is also found in Gascoigne's later book The Droomme of Doomes day, where he says that he has "collected into some ordre these sundry parcells" (George Gascoigne, The Droomme of Doomes day, in Complete Works, II, p. 213).

${ }^{65}$ Julius Caesar Scaliger, Poetices libri septem (Lyon, 1561), p. 113b. 